1. The recent Indrisinæ Chiromys, Mesopropithecus, Palcopropithecus, Archeolemur, and Hadropithecus are all more or less specialized representatives of one common Prosimian stock.

2. Specialization has taken place in various ciirections and to very rarying degrees among the different genera cnumerated; Archoolemur, Hadropithecus, and Hesopropithecus retaining on the whole the greatest number of pithecoid characters.

3. Even the least specialized forms have undergone retrogressive changes as compared with the ancestral Tertiary stock from which they, in common with the extant Indrisine, are derired. This is notably true as regards the condition of the frontal region of the brain.

4. A comparison of the least specialized nembers of this Indrisine group of Prosimix with the various families of the Old and New World Monkeys, shows in several characters closer affinities with the latter than with the former (e.g., auditory bulla, traces of primitive dentition, procumbent lower incisors, tendency to lose third molar, platyrhine condition of nasals).

5. A comparison of the Malagasy Lemurinæ, recent and sub-fossil, with the various genera of the Indrisine group supports the belief that retrogressive specialization has proceeded even further in their case than in that of the recent Indrisinæ. This retrogressive specialization has in general proceeded on similar lines in the two groups, though the deviations from the primitive dental formula are less pronounced among the Lemurine than among the Indrisine genera.

6 . The members of the family of the Lemuridæ outside of Madagasear are found in scattered groups over a wide area in the old World and bear the marks of a decalent group. All are nocturnal, and many are curiously specialized.

7. A comparison of the various genera of Lemuridx with one another and with the New World Monkeys, both recent and fossil, leads to a strong presumption that these families as well as the Malagasy Indrisine group have had a common origin.

8. In view of the recent additions to our knowledge of the Prosimix and of their close relations to the Apes, it seems no longer necessary, or indeed possible, to separate the Primates into the two suborders of Lemuroidea and Anthropoidea.

Most of the specimens described by Xr. Standing belong to the Malagasy Academy, Antananarivo, but a typical and extensive selection has been acquired by the British Museum (Natural History).

\title{
OORRESPONDENTEE.
}

\section{MARINE RIPPLE-MARK.}

SIr, - In your issue for February, p. 96, your correspondent Mr. A. R. Hunt quotes one among the many experiments $I$ showed in $\mathrm{my}$ lecture to Section $\mathrm{G}$ at Cambridge, and deduces from it that my "results and conclusions . . . . have practically no bearing on the phenomena of the sea-shore and sea-bottom."

Even had I shown only this one' experiment, such a statement would surely have been somewhat sweeping; but as I actually 
showed at the lecture "a series of periodically oscillating waves moving in one direction over a fixed bottom, and expending themselves on a sandy shore," and proved that under such wares ripples formed exactly as they did in the moving tank with rertical sides. I can only suppose that Mr. Hunt was not at the lecture, and is judging without having seen the experiments.

Hrhtha Ayrton.

71 , Norfolk Square, W.

February 28 th, 1907.

OBITUARY.

SIR FRANCIS TRESS BARRY, BART., D.L., J.P., F.S.A. Bors 1825.

Died February 28, 1907.

We regret to announce the death of Sir Francis Tress Barry, Bart., of Keiss Castle, Caithness, N.B., on the 28th February, at his Berkshire residence, St. Leonard's Hill, near Windsor, in his 83rd rear, after a long and severe illness. The late Baronet fillecl the position of British Vice-Consul for the province of Biscay, Spain, in 1846, and was Acting Consul for the provinces of Biscay, Santander, and Guipuzcoa in 1847. In $1854 \mathrm{Mr}$. Barry was offered by the Earl of Clarendon the appointment of British Consul at Madrid, but was obliged to decline it as he had established himself as a merchant at Bilbao. Retrirning to England shortly after, he joined his brother-inlaw, Mr. James Mason, in the exploitation of the famous San Domingo copper-mines in Portugal, from which time many honours fell to him. He was decorated with the Order of Christ by the King of Portugal in 1863, fire years after being raised to the rank of Commander of the same Order. In 1880 he was decorated by the King of Spain with the Cross of Naval Merit (Second Class). He acted as Consul-General in England for Ecuador in 1872. Sir Francis represented Windsor in the Conservative interest from 1890 to 1906 . He was created a Baronet in 1899, and also held the Portuguese title of Baron de Barry. Sir Francis is succeeded by his son, Major Edward Arthur Barry, who was born in 1858.-Morning Post, March 1st, 1907.

For many years Sir Francis Barry devoted himself, when at Keiss Castle, to the exploration of the numerous prehistoric towers on his estate in Caithness, known as 'Brocks.' These buildings, constructed of flat flags of Old Red Sandstone without any mortar, were extremely well built, circular in form, and originally some 30 feet in height, with solid walls of enormous thickness. Their history is quite unknown. One is still standing on Pomona, near Kirkwall, Shetlands. Those in Caithness have been destroyed, sare their foundations, which were dug out by Sir Francis Barry. He proved that they had been inhabited for long periods, the débris, or middens, containing remains of the elk, reindeer, red deer, wolf, wild boar, pig, Bos, sheep, goat, and various birds; of Ares the most interesting was the great auk (Alca impennis), of which a considerable number of entire skulls, etc., were obtained. It was Sir Francis Barry's intention to publish a full account of these most interesting prehistoric remains, but save for a small octaro pamphlet they have no record by him. 